\title{
Constitutive Ret Activity in Knock-In Multiple Endocrine Neoplasia Type B Mice Induces Profound Elevation of Brain Dopamine Concentration via Enhanced Synthesis and Increases the Number of TH-Positive Cells in the Substantia Nigra
}

\author{
Jelena Mijatovic, ${ }^{1 *}$ Mikko Airavaara, ${ }^{1 *}$ Anu Planken, ${ }^{2}$ Petri Auvinen, ${ }^{2}$ Atso Raasmaja, ${ }^{1}$ T. Petteri Piepponen, ${ }^{1}$ \\ Frank Costantini, ${ }^{3}$ Liisa Ahtee, ${ }^{1}$ and Mart Saarma ${ }^{2}$ \\ ${ }^{1}$ Division of Pharmacology and Toxicology, Faculty of Pharmacy, and ${ }^{2}$ Institute of Biotechnology, Viikki Biocenter, University of Helsinki, FIN-00014 \\ Helsinki, Finland, and ${ }^{3}$ Department of Genetics and Development, Columbia University Medical Center, New York, New York 10032
}

Ret is the common signaling receptor for glial cell line-derived neurotrophic factor (GDNF) and other ligands of the GDNF family that have potent effects on brain dopaminergic neurons. The Met918Thr mutation leads to constitutive activity of Ret receptor tyrosine kinase, causing the cancer syndrome called multiple endocrine neoplasia type B (MEN2B). We used knock-in MEN2B mice with the Ret-MEN2B mutation to study the effects of constitutive Ret activity on the brain dopaminergic system and found robustly increased concentrations of dopamine (DA) and its metabolites in the striatum, cortex, and hypothalamus. The concentrations of brain serotonin were not affected and those of noradrenaline were slightly increased only in the lower brainstem. Tyrosine hydroxylase (TH) protein levels were increased in the striatum and substantia nigra/ventral tegmental area (SN/VTA), and TH mRNA levels were increased in SN/VTA of MEN2B mice, suggesting that constitutive Ret activity increases DA levels by increasing its synthesis. Also, the striatal DA transporter protein levels in the MEN2B mice were increased, which agrees with increased sensitivity of these mice to the stimulatory effects of cocaine. In the SN pars compacta of homozygous MEN2B mice, we found a $26 \%$ increase in the number of TH-positive cells, but no differences were found in the VTA. Thus, we show here that the constitutive Ret activity in mice is sufficient to increase the number of dopaminergic neurons and leads to profound elevation of brain DA concentration. These data clearly suggest that Ret activity per se can have a direct biological function that actively changes and shapes the brain dopaminergic system.

Key words: Ret receptor; glial cell line-derived neurotrophic factor; brain dopamine; tyrosine hydroxylase; dopamine transporter; multiple endocrine neoplasia

\section{Introduction}

The Ret gene was originally discovered as an oncogene and was subsequently shown that it encodes a transmembrane receptor tyrosine kinase (RTK) (Takahashi and Cooper, 1987). Ret RTK is expressed in central motor, dopaminergic, and noradrenergic neurons and peripheral enteric, sympathetic, parasympathetic, and sensory neurons. Outside of the nervous system, Ret is detected in developing kidneys, adrenals, testicles, and thyroids (Pachnis et al., 1993; Nosrat et al., 1997; Trupp et al., 1997; Glazner et al., 1998; Golden et al., 1999).

\footnotetext{
Received June 22, 2006; revised March 6, 2007; accepted March 16, 2007.

This work was supported by the Sigrid Jusélius Foundation, Academy of Finland Systems Biology Program Grant 1105237, Centre for International Mobility, and Finnish Cultural Foundation. We thank Anni Hienola, Maria Lindahl, and Saara Nuutinen for help and Kati Rautio, Marjo Vaha, Ritva Ala-Kulju, and Tiina-Maria Peura for excellent technical assistance.

*J.M. and M.A. contributed equally to this work.

Correspondence should be addressed to Jelena Mijatovic, Division of Pharmacology and Toxicology, Faculty of Pharmacy, P.0. Box 56, FIN-00014, University of Helsinki, Finland. E-mail: jelena.mijatovic@helsinki.fi.

DOI:10.1523/JNEUROSCI.5647-06.2007

Copyright $\odot 2007$ Society for Neuroscience $\quad$ 0270-6474/07/274799-11\$15.00/0
}

Several groups almost simultaneously demonstrated that the dopaminergic neuron survival-promoting factor glial cell linederived neurotrophic factor (GDNF) signals via Ret (Durbec et al., 1996; Treanor et al., 1996; Trupp et al., 1996). GDNF and other GDNF family ligands (GFLs), such as neurturin, artemin, and persephin, bind to ligand-specific GDNF family receptor- $\alpha$ (GFR $\alpha$ ) and activate Ret by triggering transphosphorylation of tyrosine residues in its intracellular kinase domain. This leads to the activation of several intracellular cascades that regulate neuronal survival, neurite outgrowth, and synaptic plasticity (Sariola and Saarma, 2003).

Because of its potent effects on the dopaminergic system, GDNF is considered a drug candidate for the treatment of Parkinson's disease (Gill et al., 2003; Slevin et al., 2005). It exhibits survival-promoting effects on midbrain dopaminergic neurons in vitro and in vivo in animal models of Parkinson's disease (Lin et al., 1993; Hoffer et al., 1994; Tomac et al., 1995; Gash et al., 1996; Rosenblad et al., 2000), stimulates dopaminergic neuron function (Hudson et al., 1995; Beck et al., 1996; Pothos et al., 1998; 
Salvatore et al., 2004), and enhances the survival of midbrain dopaminergic neurons during postnatal development (Granholm et al., 2000; Oo et al., 2003).

Germline mutations in the Ret proto-oncogene are responsible for inherited cancer syndromes. Multiple endocrine neoplasia 2 (MEN2) is caused by constitutive Ret activation and characterized by medullary thyroid carcinoma, pheochromocytoma, and hyperparathyroidism. In MEN2A, missense mutations of the Ret gene affect the extracellular domain of the receptor and lead to its activation by covalent Ret dimerization, whereas the MEN2B subtype is associated primarily with a single activating, missense mutation of codon 918 (Met918Thr) affecting the catalytic tyrosine kinase domain (Eng, 1999; Takahashi, 2001). A mouse model for MEN2B was generated by introducing a single point mutation Met919Thr into the mouse endogenous Ret gene (Smith-Hicks et al., 2000). Both heterozygous MEN2B/+ and homozygous MEN2B/MEN2B mice display several of the major features of the human MEN2B syndrome, with earlier onset and increased severity in homozygotes.

We used MEN2B mice as a model of increased Ret activity corresponding to the continuous activation of Ret by GFLs that are involved in the maintenance and survival of central dopaminergic neurons. Ret as well as GDNF and GFR $\alpha 1$ knock-out mice die shortly after birth with no changes in dopaminergic neurons (Marcos and Pachnis, 1996; Moore et al., 1996; Pichel et al., 1996; Sanchez et al., 1996; Enomoto et al., 1998). Recently, two groups have analyzed adult mice, in which Ret was selectively deleted in dopaminergic neurons (Jain et al., 2006; Kramer et al., 2007). No changes were found in the dopaminergic system of 8- to 12month-old mice, whereas 1 - to 2 -year-old animals had decreased dopamine (DA) release and decreased number of dopaminergic neurons. Thus, we think that our Ret-MEN2B model offers an alternative approach to study the role of Ret signaling in the dopaminergic system. In addition, it has been demonstrated that neuronal cell adhesion molecule (NCAM) functions as an alternative receptor for GFLs affecting dopaminergic neurons (Chao et al., 2003; Paratcha et al., 2003). Thus, our MEN2B mouse model is specific for Ret signaling and selectively reveals its significance for the dopaminergic system in the brain.

Here, we report that the Met919Thr mutation in knock-in MEN2B mice, which renders the Ret RTK constitutively active, increases brain DA concentration and the number of TH-positive cells in the substantia nigra pars compacta $(\mathrm{SNpc})$. We also found increased TH protein levels in the striatum and substantia nigra/ ventral tegmental area (SN/VTA), as well as increased mRNA levels in the SN/VTA, suggesting that constitutive Ret activity increases DA concentration by increasing DA synthesis.

\section{Materials and Methods}

Animals

The generation and genotyping of transgenic MEN2B knock-in mice were described previously (Smith-Hicks et al., 2000). Codon 919 of murine Ret, the equivalent of human codon 918, was mutated in vitro to encode threonine rather than methionine. Briefly, a targeting vector was constructed to insert the mutant exon into the mouse genome, together with a loxP-flanked neo gene in the adjacent intron to allow positive selection. Correctly targeted ES cells were used to generate chimeric $R e t^{M E N 2 B-n e o} /+$ mice, which were mated to animals homozygous for a $\beta$-actin promoter/Cre transgene to remove the neo gene. The F1 progeny, which were heterozygous for allele $\operatorname{Ret}^{M E N 2 B}$, were intercrossed to produce $R e t^{M E N 2 B} / \operatorname{Ret}^{M E N 2 B}$ homozygotes and screened using PCR for the presence of the MEN2B mutation, using primers p5 (5'CCTCTCACACACCACAACC-3') and p6 (5'-CGAGTCAGACTCTACGACCC $\left.-3^{\prime}\right)$. The $280 \mathrm{bp}$ amplification product was generated from the wild-type (Wt) allele and the $350 \mathrm{bp}$ product from the Ret-MEN2B allele. Mice were bred locally in the Laboratory Animal Center (University of Helsinki) on a C57BL/ $6 \times 129$ Sv hybrid background and intercrossed for at least six generations. Male mice were used at 8-14 weeks of age. The chief veterinarian of the county administrative board approved the experimental setup. The experiments were conducted according to the European Convention for the Protection of Vertebrate Animals used for Experimental and other Scientific Purposes. The mice were housed in groups of two to eight to a cage and had ad libitum access to mouse chow and water. They were maintained under a $12 \mathrm{~h}$ light/dark cycle with lights on from 6:00 A.M. to 6:00 P.M. and at an ambient temperature of $20-22^{\circ} \mathrm{C}$.

\section{Brain dissection}

The mice were killed by decapitation, and their brains were rapidly removed from the skull and placed on an ice-cold brain matrix (Stoelting, Wood Dale, IL).

The hypothalamus was dissected by cutting its borders to a depth of 2 $\mathrm{mm}$ and then pinching it out with forceps. Thereafter, two coronal cuts were made by razor blades at approximately -2.8 and $-3.88 \mathrm{~mm}$ from bregma [according to the atlas of Franklin and Paxinos (1997)] and from the obtained section, an area that contains SN/VTA was punched with a sample corer ( $1 \mathrm{~mm}$ inner diameter) with a plunger (Fine Science Tools, Heidelberg, Germany). The rostral part of the brain was turned to expose the dorsal surface and moved on an ice-cold plate, and the cortical hemispheres were separated by cutting the corpus callosum and spread apart. The hippocampi were peeled from adjacent cortical tissue. The medial borders of the striata were freed, and the striata (dorsal and ventral striatum) were pinched off with forceps. Finally, the cortex was dissected from the rest of the forebrain. From the caudal part of the brain, the cerebellum was discarded and a coronal cut was made at the caudal end of the fossa rhomboidea. Then, the lower brainstem containing the locus ceruleus (LC) was separated from the midbrain by a cut at an angle of $45^{\circ}$ starting dorsally at the rostral border of colliculi anterior/posterior and ending ventrally at the rostral border of the pons.

To examine the effects of Ret-MEN2B mutation on nigrostriatal and mesolimbic dopaminergic systems, we dissected dorsal and ventral striata apart. Brains were removed from the skull and placed on an ice-cold mouse brain matrix, and two coronal cuts were made by razor blades at $\sim 1.5$ and $-0.3 \mathrm{~mm}$ from bregma. From the obtained section, the dorsal striatum was punched below the corpus callosum by using a sample corer (inner diameter, $2 \mathrm{~mm}$ ). Another piece of tissue, referred to as the nucleus accumbens (NAc), but containing in addition to NAc shell and core, the ventral pallidum as well as parts of the piriform cortex, bed nucleus of the stria terminalis, and anterior amygdaloid area, was punched from the same slice. The same sample corer was placed ventromedially to the circle that was already made so that the second circle would slightly overlap with the first one at the lower ventral end. Dissected tissue pieces were immediately placed into frozen microcentrifuge tubes and, after weighing, they were stored at $-80^{\circ} \mathrm{C}$ until assayed.

\section{Estimation of monoamines and their metabolites}

Concentrations of the following substances from brain samples were analyzed using HPLC with electrochemical detection as described by Airavaara et al. (2006): DA, dihydroxyphenylacetic acid (DOPAC), homovanillic acid (HVA), noradrenaline (NA), 3-methoxy-4hydroxyphenylethylenglycol (MOPEG), serotonin (5-HT), and 5 -hydroxyindolacetic acid (5-HIAA). The values of monoamines and their metabolites are presented as nanograms per gram wet weight of tissue.

\section{Immunohistochemistry}

The mice were anesthetized with sodium pentobarbital (100 mg/kg, i.p.) and perfused intracardially with PBS followed by $4 \%$ paraformaldehyde in $0.1 \mathrm{M}$ sodium phosphate buffer, $\mathrm{pH}$ 7.4. The brains were removed, postfixed for $4 \mathrm{~h}$, and stored in sodium phosphate buffer containing $20 \%$ sucrose at $4^{\circ} \mathrm{C}$. Coronal striatal and nigral sections were cut and saved individually in serial order at $-20^{\circ} \mathrm{C}$ until used for either $\mathrm{TH}$ or DA transporter protein (DAT) immunostaining. 
TH immunohistochemistry. The striatal and nigral $(40 \mu \mathrm{m})$ freefloating sections were stained using standard immunohistochemical procedures. Brains from 11 to 12 animals were processed at a time, and animals from all three genotypes were included in every run. After rinsing with PBS three times for $10 \mathrm{~min}$, sections were quenched with $3 \%$ hydrogen peroxide $\left(\mathrm{H}_{2} \mathrm{O}_{2}\right)$ and $10 \%$ methanol for $5 \mathrm{~min}$ and rinsed again in PBS three times for $10 \mathrm{~min}$. Sections were preincubated in $2 \%$ normal goat serum (NGS; Vector Laboratories, Burlingame, CA) and 0.3\% Triton X-100 in PBS for $60 \mathrm{~min}$ at room temperature to block nonspecific staining. Thereafter, the sections were incubated with rabbit anti-TH polyclonal antibody (Millipore, Bedford, MA) and diluted 1:2000 in PBS containing NGS (2\%) and Triton X-100 (0.3\%) overnight under gentle shaking. The sections were then rinsed in PBS three times for $10 \mathrm{~min}$ and incubated for $2 \mathrm{~h}$ with the biotinylated goat anti-rabbit antibody (Vector Laboratories) at 1:200 in PBS containing $0.3 \%$ Triton X-100 at room temperature. The sections were rinsed in PBS three times for $10 \mathrm{~min}$ and then the standard avidin-biotin reaction was performed using Vectastain Elite ABC peroxidase kit (Vector Laboratories) following the protocol suggested by the manufacturer. The immunoreactivity was revealed using $0.06 \%$ diaminobenzidine and $0.03 \% \mathrm{H}_{2} \mathrm{O}_{2}$ diluted in PBS and afterward rinsed twice with phosphate buffer. The sections were mounted on gelatin/chrome alume-coated slides, air-dried overnight, dehydrated through graded ethanols, cleared in xylene, and coverslipped with Pertex mounting medium (Cellpath, Hemel Hempstead, UK).

$D A T$ immunohistochemistry. Striatal free-floating sections used for densitometry measurements $(40 \mu \mathrm{m})$ were processed as described above for $\mathrm{TH}$, with the exception that the primary antibody was a rat anti-DAT monoclonal antibody at 1:2000 (Millipore), the secondary antibody was biotinylated rabbit anti-rat antibody at 1:200, and normal rabbit serum (Vector Laboratories) was used instead of NGS. Striatal sections $(30 \mu \mathrm{m})$ used for stereological estimation of DAT-positive varicosities were incubated for $48 \mathrm{~h}\left(\right.$ at $\left.4^{\circ} \mathrm{C}\right)$, and the concentration of primary antibody was increased to 1:1000 (Millipore).

Striatal densitometry measurements. Striatal TH-positive and DATpositive fiber staining was assessed by optical density (OD) measurements. Using an Optronics (Goleta, CA) digital camera and a constant illumination table, digitalized images of $\mathrm{TH}$ and DAT immunostained striatal sections were collected. ODs were measured using Image-Pro Plus software (Version 3.0.1; Media Cybernetics, Silver Spring, MD). For each animal, the OD was measured from three striatal coronal sections and the final reading was calculated as an average of those three values. The nonspecific background correction in each section was done by subtracting the OD value of the corpus callosum from the striatal OD value obtained from the same section. The OD analysis was performed under blinded condition on coded slides.

Stereological analysis of TH-positive cells and DAT-positive varicosities. The number of TH-positive neurons in the SNpc and VTA, and the density of DAT-immunoreactive varicosities in the striatum, were estimated by a person blinded to the identity of the samples. The numbers of $\mathrm{TH}$-positive neurons in the SNpc were assessed as described previously (Sauer et al., 1995). In brief, the cell number was quantified from the SNpc by using the medial terminal nucleus (MTN) of the accessory optic tract as its medial border. From each animal, three sections where the MTN is present (between levels -2.92 and -3.28 from bregma, every second section) were selected, and all stained neurons lateral to the MTN were counted. TH-positive somas were used as the counting unit. StereoInvestigator (MBF Bioscience, Williston, VT) was used to estimate THpositive cells with optical fractionator according to optical dissector rules (Gundersen et al., 1988). Optical fractionator was optimized so that the values of the coefficient of error $(\mathrm{CE})<0.1$ were accepted. Cell counts were made using a $60 \times$ oil objective [Olympus BX51 (Olympus Optical, Tokyo, Japan) equipped with an Optronics camera]. After SNpc estimations were performed, the same sections were used for counting the TH-positive cells in the VTA, using a $60 \times$ oil objective. TH staining was used to define the outline of the VTA with the MTN as the lateral border.

The number of DAT-immunoreactive (DAT-IR) punctuate structures in the striatum was determined using a stereology approach similar to that described previously (Parish et al., 2001). Every fifth striatal section from planes 1.1 and 0.38 from bregma (four sections from each striatum) was analyzed at $100 \times$ under oil. The entire striatum on one side of the brain was analyzed. The DAT-positive terminals were identified as round swellings in association with axons and used as counting units. The total numbers of the DAT-positive punctuate structures for each striatum, on one side, was determined by the StereoInvestigator program. The CE was calculated as an estimate of precision, and values $<0.1$ were accepted. The volume of the SNpc and VTA portions used for TH-positive neuron counting and volume of the striatum portion used for DAT-positive terminal counting for each brain was determined by the StereoInvestigator program.

\section{Western blotting}

Western blotting was performed for TH from tissues of dorsal striatum and SN/VTA and DAT from dorsal striatal tissue. Individual striata were homogenized in lysis buffer containing 5 mM HEPES, pH 7.4, $320 \mathrm{~mm}$ sucrose, $1 \mathrm{~mm}$ EDTA, $0.1 \mathrm{~mm}$ PMSF, and $0.1 \%$ SDS. The homogenates were centrifuged at $900 \times g$ for $3 \mathrm{~min}$, and the supernatants were further centrifuged at $16,000 \times g$ for $20 \mathrm{~min}$. Supernatant fraction was used for analysis, and its protein concentration was determined with a BCA kit (Pierce, Rockford, IL). The samples were diluted in Laemmli buffer so that $15 \mu \mathrm{g}$ of protein were loaded on and electrophoresed in a $7.5 \%$ SDS-polyacrylamide gel and transferred onto Protran nitrocellulose transfer membrane (Schleicher and Schuell Bioscience, Dassel, Germany). After blocking of nonspecific binding with 5\% nonfat dry milk, the membranes were then probed with sheep anti-TH polyclonal antibody (1:1000; Millipore) and rat anti-DAT monoclonal antibody (1:500; Millipore). Next, membranes were treated with appropriate secondary antibody (1:2000) conjugated with horseradish peroxidise (HRP), and blots were visualized with chemiluminescent substrate (Pierce) detected and estimated using GeneGnome chemiluminescent detector and its software (SynGene; Synoptics, Cambridge, UK). The membranes were then stripped of antibodies and afterward reprobed with mouse antiactin antibody at 1:10,000 (Sigma, St. Louis, MO) and appropriate antimouse HRP-conjugated secondary antibody (1:2000; Zymed, San Francisco, CA). The stripping protocol included shaking the membranes in $40 \%$ methanol for $30 \mathrm{~min}$ at room temperature, followed by submersion in stripping buffer containing the following: $2 \%$ SDS, $62.5 \mathrm{~mm}$ Tris $\mathrm{HCl}$, $100 \mathrm{~mm} \beta$-mercaptoethanol, at $55^{\circ} \mathrm{C}$ for $30 \mathrm{~min}$. Five percent nonfat milk was used for blocking.

Dissected SN/VTA tissues of five mice of the same genotype were pooled and afterward processed as one sample. The SN/VTA samples were homogenized in ice-cold lysis buffer (TBS with 1\% NP40, 10\% glycerol, $1 \mathrm{~mm}$ PMSF, and complete mini protease inhibitor mixture tablets; Roche Products, Welwyn Garden City, UK). Normalized amounts of protein sample $(10 \mu \mathrm{g})$ were loaded on a $10 \%$ SDSpolyacrylamide gel, transferred onto a Hybond ECL Nitrocellulose membrane (GE Healthcare, Arlington Heights, IL) that was then probed with anti-TH antibody, and subsequently treated with HRP-conjugated secondary antibody. The blots were visualized by chemiluminescent substrate (Pierce). The images were taken using an LAS 3000 CCD Camera from Fujifilm (Tokyo, Japan) and quantified using the AIDA Image Analyzer software.

\section{Real-time PCR}

Dissected VTA/SN samples from six mice per genotype were pooled. Total RNA was isolated using Trizol (Invitrogen, Carlsbad, CA), followed by purification with RNeasy Mini kit (Qiagen, Valencia, CA).

Primer design. Primer pairs were designed using the ABI Prism Primer Express software version 2.0. The criteria for primer design were as follows: short amplicon size ( $50-150 \mathrm{bp}$ ), melting temperature $\sim 60^{\circ} \mathrm{C}$, low G-C content, starting from the $3^{\prime}$ end, and spanning an intron-exon boundary. Primer sequences included the following: ACTIN-F-5'ATGGAATCCTGTGGCATCCAT-3', ACTIN-R-5' -CCACCAGACAACACTGTGTTGG-3', NEUROFILAMENT-F-5' -CTGCAGTCCAAGAGCATCGA-3', NEUROFILAMENT-R-5' -ACTGCTGGATGGTGTCCTGG-3', TH-F-5'-CACAGCTGGAGGATGTGTCTCA-3', TH-R5'-AGAAAATCACGGGCAGACAGTAG-3' ${ }^{\prime}$, DAT-F-5' ${ }^{\prime}$-TCAGCCTGTGGAAGGGAGTAA-3', DAT-R-5'-ACATAGGGCATGGTAGCTGTGA-3'. The products ranged from 100 to $200 \mathrm{bp}$. All primers amplified a single peak at the correct melting point on the dissociation curve. 
Table 1. DA, DOPAC, and HVA concentrations (nanograms per gram of wet tissue) in the striatum, cortex, hypothalamus, and lower brainstem of Wt and knock-in heterozygous MEN2B/+ and homozygous MEN2B/MEN2B mice

\begin{tabular}{|c|c|c|c|c|c|}
\hline & $\mathrm{DA}$ & DOPAC & HVA & DOPAC/DA & HVA/DA \\
\hline \multicolumn{6}{|l|}{ Striatum } \\
\hline Wt & $14458 \pm 682$ & $1019 \pm 48$ & $1508 \pm 129$ & $0.071 \pm 0.03$ & $0.105 \pm 0.09$ \\
\hline MEN2B/+ & $21251 \pm 981^{* *}$ & $1535 \pm 50^{* *}$ & $1966 \pm 140$ & $0.073 \pm 0.03$ & $0.093 \pm 0.05$ \\
\hline MEN2B/ MEN2B & $28974 \pm 1375^{* * *^{b}}$ & $2530 \pm 199^{* *, b}$ & $3134 \pm 267^{* *_{1}^{b}}$ & $0.087 \pm 0.03^{*, b}$ & $0.109 \pm 0.01$ \\
\hline \multicolumn{6}{|l|}{ Cortex } \\
\hline Wt & $707 \pm 42$ & $96 \pm 6$ & $95 \pm 7$ & $0.137 \pm 0.01$ & $0.134 \pm 0.01$ \\
\hline MEN2B/+ & $1188 \pm 67^{* *}$ & $155 \pm 11^{*}$ & $150 \pm 12^{*}$ & $0.132 \pm 0.18$ & $0.127 \pm 0.01$ \\
\hline MEN2B/ MEN2B & $1232 \pm 129^{* *}$ & $207 \pm 25^{* *}$ & $180 \pm 25^{* *}$ & $0.168 \pm 0.01^{a}$ & $0.151 \pm 0.02$ \\
\hline \multicolumn{6}{|l|}{ Hypothalamus } \\
\hline Wt & $588 \pm 55$ & $153 \pm 8$ & $155 \pm 12$ & $0.28 \pm 0.03$ & $0.29 \pm 0.04$ \\
\hline MEN2B/+ & $608 \pm 26$ & $182 \pm 9$ & $214 \pm 17$ & $0.30 \pm 0.02$ & $0.36 \pm 0.03$ \\
\hline MEN2B/ MEN2B & $775 \pm 59^{*}$ & $264 \pm 43^{* *, b}$ & $298 \pm 64^{* *}$ & $0.29 \pm 0.02$ & $0.32 \pm 0.06$ \\
\hline \multicolumn{6}{|l|}{ Lower brainstem } \\
\hline Wt & $32 \pm 3$ & $42 \pm 5$ & $47 \pm 7$ & $1.33 \pm 0.1$ & $1.49 \pm 0.17$ \\
\hline MEN2B/+ & $33 \pm 1$ & $42 \pm 3$ & $44 \pm 7$ & $1.30 \pm 0.1$ & $1.32 \pm 0.15$ \\
\hline MEN2B/ MEN2B & $41 \pm 6$ & $48 \pm 5$ & $46 \pm 6$ & $1.31 \pm 0.2$ & $1.08 \pm 0.15$ \\
\hline
\end{tabular}

The DOPAC/DA and HVA/DA ratios are also shown. Data are expressed as means \pm SEM. One-way ANOVA and Tukey-Kramer post hoc test were used for statistical analysis. ${ }^{*} p<0.05,{ }^{* *} p<0.01$ when compared with Wt mice. $n=6-10$ mice per group.

${ }^{a} p<0.05$ when compared with $\mathrm{MEB} 2 \mathrm{~B} /+$ mice.

${ }^{b} p<0.01$ when compared with $M E B 2 B /+$ mice.

cDNA synthesis and quantitative PCR. cDNA from $600 \mathrm{ng}$ of mRNA was synthesized using the TaqMan reverse transcription reagents by Applied Biosystems (Foster City, CA). Triplicate quantitative PCRs for each gene contained cDNA, primer mixture (300 pmol), and SYBR green PCR master mixture (Applied Biosystems). Real-time PCR was performed using ABI Prism 7000 SDS (Applied Biosystems). The thermal profile included the following steps: $2 \mathrm{~min}$ at $50^{\circ} \mathrm{C}, 10 \mathrm{~min}$ at $95^{\circ} \mathrm{C}, 15 \mathrm{~s}$ at $95^{\circ} \mathrm{C}$, and $1 \mathrm{~min}$ at $60^{\circ} \mathrm{C}$, followed by a dissociation curve analysis.

Calculations. For data analysis, the comparative threshold cycle (CT) method was used. The $\Delta \mathrm{CT}$ for each primer pair is determined by subtracting the $\Delta \mathrm{CT}$ for control gene actin and neurofilament. Then the $\Delta \Delta \mathrm{CT}$ is calculated by subtracting the control sample value (Wt) from the experimental sample (MEN2B/MEN2B). The fold change for each gene is expressed as $2^{-\Delta \Delta \mathrm{CT}}$.

\section{Locomotor activity experiments}

To measure spontaneous locomotor activity, the mice were placed individually in transparent plastic cages $(24 \times 24 \times 15 \mathrm{~cm})$ with perforated plastic lids without previous habituation, and infrared photobeam interruptions were registered for $60 \mathrm{~min}$. The cages were placed in activity monitors (open-field activity monitor; MED Associates, St. Albans, GA). In the $24 \mathrm{~h}$ activity experiment, the same mice were habituated individually for $2 \mathrm{~h}$ in the experimental cages on the day before the experiment, and they were placed in the cages $2 \mathrm{~h}$ before the experiment started. New sawdust covered the bottom of the cage, and the mice had ad libitum access to food and water. Infrared photobeam interruptions were registered at intervals of $90 \mathrm{~min}$ for $24 \mathrm{~h}$ starting at 10:30 A.M. In the cocaine experiment, all mice were given saline $(0.9 \% \mathrm{NaCl}$, i.p. $)$ on the first experimental day, and on the next day, cocaine- $\mathrm{HCl}(5,10$, or $20 \mathrm{mg} / \mathrm{kg}$ as base; $10 \mathrm{ml} / \mathrm{kg}$, i.p; University Pharmacy, Helsinki, Finland). The mice were individually placed in the cages and habituated for $\geq 15 \mathrm{~min}$ before the injections. The locomotor activity of the mice was monitored for 30 min immediately after the injections. The same mice were used throughout the locomotor activity experiments. The spontaneous locomotor activity was measured on day 1 , the $24 \mathrm{~h}$ activity experiment was performed on days 3 and 4 , and the saline plus cocaine experiment on days 5 and 6. Tests were started between 8:00 and 10:00 A.M.

\section{Statistics and data analysis}

Locomotor activity data were analyzed with two-way ANOVA for repeated measures, and the Tukey-Kramer post hoc test was used when significant interaction $(p<0.05)$ was found. Data obtained from monoamine and densitometry measurements were analyzed with one-way ANOVA, and post hoc comparisons were performed by the Tukey-
Kramer test. TH-positive cell numbers and numbers of DAT-positive varicosities of $\mathrm{Wt}$ and homozygous MEN2B mice were compared by unpaired Student's $t$ test. All results presented are means \pm SEM.

\section{Results}

\section{Brain monoamine concentrations}

Striatum, cortex, hypothalamus, lower brainstem area, and hippocampus

Table 1 shows the concentrations of DA and its metabolites in $\mathrm{Wt}$, homozygous (MEN2B/MEN2B), and heterozygous $(\mathrm{MEN} 2 \mathrm{~B} /+)$ mice. The striatal concentrations of DA were significantly elevated in homozygous MEN2B/MEN2B (by 100\%) and heterozygous MEN2B/+ (by 47\%) mice compared with $\mathrm{Wt}$ mice. In addition, the striatal concentrations of DA metabolites, DOPAC and HVA, were significantly higher in homozygous MEN2B/MEN2B (DOPAC by $148 \%$; HVA by $108 \%$ ) and heterozygous MEN2B/+ (DOPAC by $50 \%$; HVA by $30 \%$ ) mice than in the Wt mice and also significantly higher in homozygous mice than in heterozygous mice (Table 1). Whereas HVA/DA ratios were alike in all three genotypes, DOPAC/DA ratios were significantly increased in homozygous MEN2B mice compared with mice of the other two genotypes ( $p=0.0039$; one-way ANOVA).

Cortical DA, DOPAC, and HVA concentrations were significantly higher in homozygous (DA by $74 \%$; DOPAC by $116 \%$; HVA by $89 \%$ ) and heterozygous (DA by $68 \%$; DOPAC by $61 \%$; HVA by $58 \%$ ) mice than in the Wt mice (Table 1 ), and the DOPAC/DA ratio was significantly higher in the homozygous than in the heterozygous MEN2B mice. In the hypothalamus, the concentrations of DA and its metabolites were significantly elevated only in the homozygous mice (DA by 32\%; DOPAC by $73 \%$; HVA by $92 \%$ ) compared with the $\mathrm{Wt}$ mice. In the lower brainstem, the concentrations of DA and its metabolites were small and almost similar in the mice of the three genotypes.

\section{Dorsal and ventral striatum}

Next, we wanted to study whether the nigrostriatal and mesolimbic dopaminergic systems of MEN2B mice are differently affected by the Ret-MEN2B mutation. For that purpose, we dissected the dorsal and ventral striatum separately (see Materials and Methods) and measured tissue monoamine concentrations in each. As 


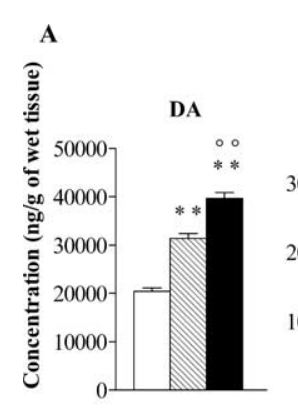

Dorsal striatum

B

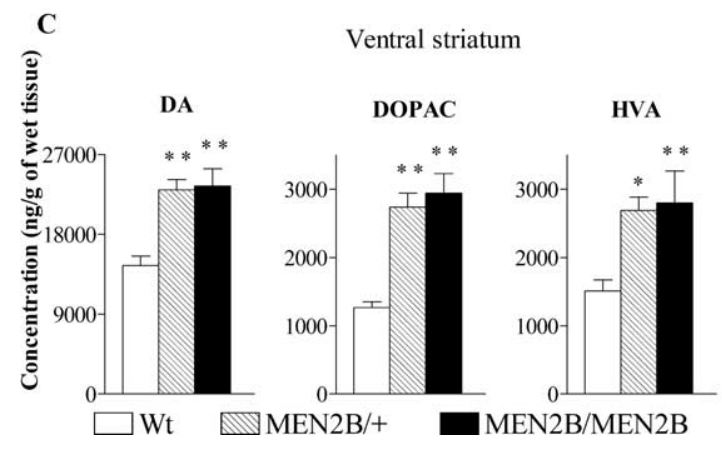

Figure 1. Concentrations (nanograms per gram) of DA and its metabolites, DOPAC and HVA, in the dorsal $(\boldsymbol{A})$ and ventral $(\boldsymbol{C})$ striatum of Wt, heterozygous MEN2B/+, and homozygous MEN2B/MEN2B mice. Also shown are the DOPAC/DA and HVA/DA ratios in the dorsal $(\boldsymbol{B})$ and ventral $(\boldsymbol{D})$ striatum. Data are means \pm SEM. Note that the scales in the figures differ. Statistical results were obtained with one-way ANOVA and Tukey-Kramer post hoc analysis. ${ }^{*} p<0.05,{ }^{* *} p<0.01$, when compared with Wt mice; ${ }^{\circ} p<0.05,{ }^{\circ 0} p<0.01$ when compared with MEB2B $/+$ mice; $n=6-23$.

Table 2. 5-HT, 5-HIAA, NA, and MOPEG concentrations (nanograms per gram of wet tissue) in the striatum, cortex, hypothalamus, hippocampus, and lower brainstem areas of $\mathrm{Wt}$, heterozygous $\mathrm{MEN} 2 \mathrm{~B} /+$, and homozygous MEN2B/MEN2B mice

\begin{tabular}{|c|c|c|c|c|}
\hline & NA & MOPEG & 5-HT & 5-HIAA \\
\hline \multicolumn{5}{|l|}{ Striatum } \\
\hline Wt & nd & nd & $486 \pm 29$ & $252 \pm 24$ \\
\hline MEN2B/+ & nd & nd & $518 \pm 29$ & $242 \pm 20$ \\
\hline MEN2B/MEN2B & nd & nd & $509 \pm 17$ & $262 \pm 21$ \\
\hline \multicolumn{5}{|l|}{ Cortex } \\
\hline Wt & $369 \pm 11$ & $7.0 \pm 0.67$ & $222 \pm 13$ & $32 \pm 3$ \\
\hline MEN2B/+ & $382 \pm 17$ & $6.7 \pm 0.78$ & $240 \pm 17$ & $34 \pm 3$ \\
\hline MEN2B/MEN2B & $360 \pm 13$ & $6.5 \pm 0.86$ & $235 \pm 8$ & $36 \pm 3$ \\
\hline \multicolumn{5}{|l|}{ Hypothalamus } \\
\hline Wt & $1731 \pm 58$ & $71 \pm 1.6$ & $1113 \pm 51$ & $244 \pm 20$ \\
\hline MEN2B/+ & $1674 \pm 77$ & $71 \pm 2.3$ & $1072 \pm 36$ & $262 \pm 23$ \\
\hline MEN2B/ MEN2B & $1947 \pm 58$ & $73 \pm 2.5$ & $1166 \pm 73$ & $287 \pm 55$ \\
\hline \multicolumn{5}{|l|}{ Hippocampus } \\
\hline Wt & $582 \pm 19$ & $43.8 \pm 2$ & $516 \pm 28$ & $164 \pm 11$ \\
\hline MEN2B/+ & $571 \pm 20$ & $40.7 \pm 1$ & $471 \pm 12$ & $153 \pm 13$ \\
\hline MEN2B/ MEN2B & $548 \pm 14$ & $37.8 \pm 2$ & $477 \pm 12$ & $119 \pm 24$ \\
\hline \multicolumn{5}{|l|}{ Lower brainstem } \\
\hline Wt & $790 \pm 29$ & $62 \pm 4$ & $611 \pm 19$ & $359 \pm 38$ \\
\hline MEN2B/+ & $871 \pm 27$ & $63 \pm 3$ & $622 \pm 30$ & $334 \pm 29$ \\
\hline MEN2B/MEN2B & $1002 \pm 53^{* *{ }^{a}}$ & $69 \pm 4$ & $658 \pm 24$ & $344 \pm 23$ \\
\hline
\end{tabular}

Data are expressed as means \pm SEM. One-way ANOVA and Tukey/Kramer post hoc test were used for statistical analysis. ${ }^{* *} p<0.01$ when compared with wild- type mice. $n=6-10$ per group. nd, Not detected.

${ }^{a} p<0.05$ when compared with MEB2B $/+$ mice.

shown in Figure $1 A$, concentrations of DA in the dorsal striatum were significantly increased in both homozygous MEN2B/ MEN2B (by 94\%) and heterozygous MEN2B/+ (by 54\%) mice compared with Wt mice. Also, DOPAC and HVA concentrations were significantly increased in the homozygous (DOPAC by $185 \%$; HVA by $137 \%$ ) and in the heterozygous (DOPAC by $102 \%$; HVA by $72 \%$ ) mice (genotype effect for DA, DOPAC, and
HVA, $p<0.0001$; one-way ANOVA). Furthermore, DA, DOPAC, and HVA concentrations were significantly higher in the homozygous MEN2B/MEN2B mice than in the heterozygous $\mathrm{MEN} 2 \mathrm{~B} /+$ mice $(p<0.05$ to $p<0.01$; Tukey-Kramer post hoc analysis) (Fig. $1 A$ ). In the dorsal striatum, we found higher DOPAC/DA ratios in both MEN2B/MEN2B and MEN2B/+ mice compared with Wt mice, without any difference in HVA/DA ratio values (genotype effect for DOPAC/DA ratio in the dorsal striatum, $p<0.0001$; one-way ANOVA) (Fig. $1 B$ ).

In the ventral striatum, DA concentrations of the homozygous MEN2B/MEN2B and heterozygous $\mathrm{MEN} 2 \mathrm{~B} /+$ mice were $\sim 60 \%$ higher than those in the Wt mice. Also, the concentrations of DOPAC and HVA in the ventral striatum of these mice were significantly elevated (DOPAC by $120-130 \%$; HVA by $80 \%$ ) compared with Wt mice (genotype effect for DA and DOPAC, $p<0.0001$ and for HVA, $p=$ 0.0032; one-way ANOVA) (Fig. $1 B$ ). The DOPAC/DA ratios in the ventral striatum were significantly higher in both homozygous MEN2B/MEN2B and heterozygous mice compared with the Wt mice (genotype effect for DOPAC/DA ratio, $p<$ 0.005; one-way ANOVA) (Fig. 1D). As in the whole striatum and dorsal striatum, HVA/DA ratios did not differ between the genotypes. DA concentrations significantly differed between heterozygous and homozygous MEN2B mice only in the dorsal striatum, whereas in the ventral striatum as well as in the cortex, the elevations in homozygous and heterozygous MEN2B mice were similar. These findings suggest that DA levels in mesocorticolimbic dopaminergic neurons are already maximally elevated at a lower Ret dose, indicating that they are more sensitive to the dopamine-elevating effects of RetMEN2B signaling.

The increased DOPAC/DA ratios in homozygous and heterozygous MEN2B mice, without changes in HVA/DA ratio values, indicate that the levels of DOPAC were increased even more than the levels of HVA. DOPAC is a metabolite of DA, which is mainly intracellularly produced (Roffler-Tarlov et al., 1971), and HVA is formed outside of the dopaminergic neurons and is a secondary metabolite of DA derived either from DOPAC or 3-MT (3-methoxytyramine) and reflecting DA release (Wood and Altar, 1988). These results suggest that intracellular rather than extracellular levels of DA are increased in MEN2B mice. As Table 2 shows, the concentrations of 5-HT and its metabolite 5-HIAA were similar within the three genotypes in all five brain areas studied. Also, we found that NA concentrations did not differ between the mice of the three geno- 


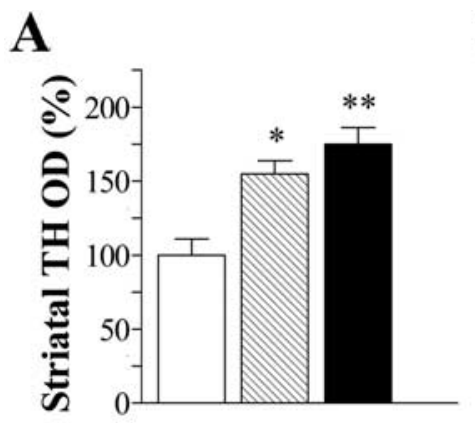

C

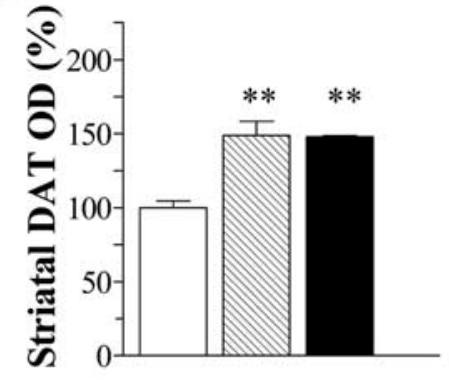

$\square$ Wt $\mathbb{M}$ MEN2B/+
B

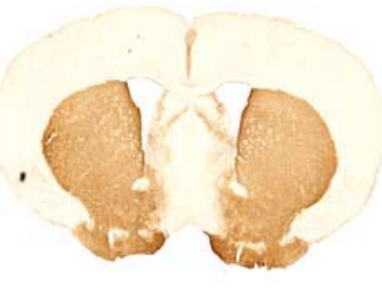

$\mathrm{Wt}$

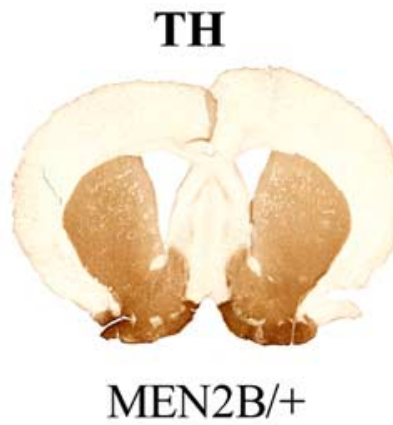

MEN2B/+

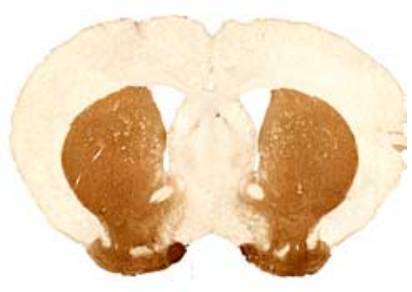

MEN2B/MEN2B
D
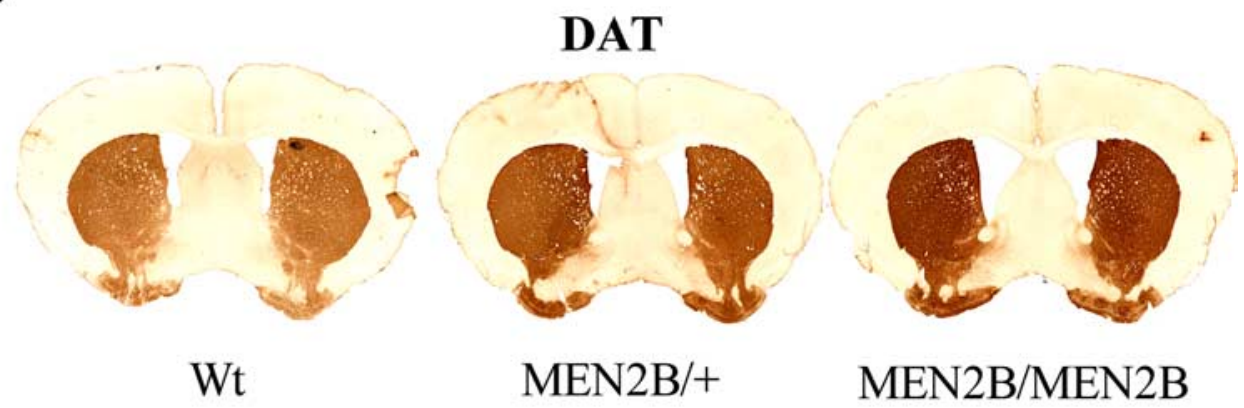

MEN2B/MEN2B

Figure 2. TH and DAT expression in striata of MEN2B mice compared with Wt mice. $A, 0 D$ measurements in TH-immunostained striatal sections revealed 55 and $75 \%$ increases in striatal TH immunoreactivity in MEN2B/+ and MEN2B/MEN2B mice, respectively, compared with Wt mice. $\boldsymbol{B}, \boldsymbol{D}$, Photomicrographs are from TH $(\boldsymbol{B})$ and DAT $(\boldsymbol{D})$ immunostained striatal sections. $\boldsymbol{C}, 0 \mathrm{D}$ measurements in DAT-immunostained striatal sections showed $\sim 50 \%$ increase in striatal DAT-immunoreactivity in mice of both MEN2B genotypes compared with the Wt mice. Data in $A$ and $C$ are expressed as percentages of Wt values set as 100\%. Data are means \pm SEM ( $n=4$ animals per group; 3 sections per animal). One-way ANOVA and Tukey-Kramer post hoc test were used for statistical analysis. ${ }^{*} p<0.05,{ }^{* *} p<0.01$ when compared with Wt mice.

types except in the lower brainstem, where we found $27 \%$ increased NA concentration in homozygous MEN2B mice compared with the Wt mice (Table 2). The lower brainstem contains cell bodies of noradrenergic neurons projecting from the LC, which almost exclusively innervate the forebrain areas like the ventral striatum, cortex, and hippocampus (Hokfelt et al., 1984). Because concentrations of NA and its metabolite, MOPEG, in these brain parts did not differ between the MEN2B and Wt mice (Table 2), these results indicate that Ret-MEN2B mutation did not affect the LC neurons.

\section{TH and DAT expression}

Our findings that in the MEN2B mice both the cerebral concentrations of DA and its metabolites are increased indicate that the increased DA concentration does not result from reduced metabolism but rather from enhanced synthesis. Therefore, we next examined levels of two physiologically important dopaminergic markers, $\mathrm{TH}$ and DAT, in the striata of these mice. Densitometry measurements of striatal $\mathrm{TH}$-immunostained sections revealed 55 and $75 \%$ increases in $\mathrm{TH}$-positive fiber staining in the heterozygous MEN2B/+ and homozygous MEN2B/MEN2B mice, respectively, compared with the $\mathrm{Wt}$ mice ( $p=0.003$; one-way ANOVA) (Fig. 2A). Increase in the striatal DAT-positive fiber staining was $\sim 50 \%$ in both MEN2B/MEN2B and MEN2B/+ mice compared with Wt mice ( $p=0.004$; one-way ANOVA) (Fig. 2C). Increase in striatal TH and DAT proteins was confirmed by Western blot analyses in the striatal tissue samples (Fig. $3 A$ ). In addition, Western blot analysis in SN/VTA revealed that $\mathrm{TH}$ protein levels were $\sim 180$ and $60 \%$ increased in homozygous MEN2B/MEN2B and heterozygous MEN2B/+ mice, respectively, compared with their Wt littermates (Fig. 3B).

Using quantitative real-time PCR we found $\sim 2.5$-fold increase in levels of TH mRNA in the SN/VTA of MEN2B/MEN2B mice compared with $\mathrm{Wt}$ mice (Wt, $1.06 \pm 0.09$; MEN2B/ MEN2B, $2.54 \pm 0.49 ; n=5-6 ; p=0.04$; Student's $t$ test). We also observed $\sim 2.7$-fold increase in the levels of DAT mRNA in SN/ 


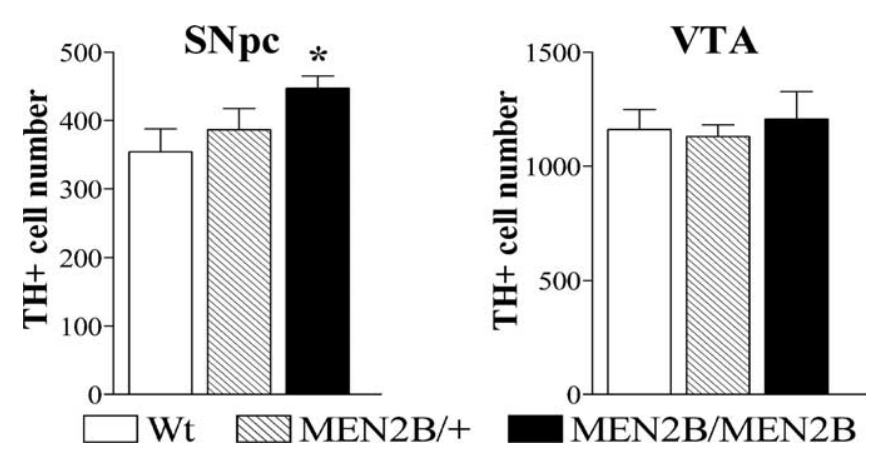

Figure 4. Number of TH-positive neurons in SNpc and VTA of Wt, heterozygous MEN2B/+, and homozygous MEN2B/MEN2B mice. Coronal midbrain sections that were immunostained for TH and TH + cells were counted in the SNpc (left) and VTA (right) from the same brain slices using stereology as described in the Materials and Methods. Data are means \pm SEM. $n=6-10$ mice. The number of SNpc TH-positive cells in homozygous MEN2B/MEN2B mice was increased by $26 \%$ compared with the Wt mice ( ${ }^{*} p<0.05$ vs Wt mice; Student's $t$ test), whereas no difference in the number of TH + cells in the VTA was found between the genotypes.

VTA of homozygous MEN2B mice, although it did not reach statistical significance $(\mathrm{Wt}, 1.09 \pm 0.24 ; \mathrm{MEN} 2 \mathrm{~B} / \mathrm{MEN} 2 \mathrm{~B}, 2.79 \pm$ $0.72 ; p=0.067$; Student's $t$ test). The other genes studied, such as GDNF, GFR $\alpha 1$, NCAM, DOPA decarboxylase, and DA D1receptor, were screened in the SN/VTA, and no changes in their expression were found (data not shown). In the striatum, no change in the expression of GDNF was observed (Wt, $1.00 \pm$ $0.12 ; \mathrm{MEN} 2 \mathrm{~B} / \mathrm{MEN} 2 \mathrm{~B}, 1.2 \pm 0.11$ ).

\section{TH-positive neurons in the SN/VTA}

To determine whether the sustained activity of the Ret receptor in knock-in MEN2B mice has an effect on the number of dopaminergic neurons in SNpc and VTA, we performed a stereological analysis on TH-stained sections. This analysis revealed a $26 \%$ increase in the number of TH-positive neurons in the homozygous MEN2B/MEN2B mice compared with their Wt littermates ( $p=0.0246$; Student's $t$ test) (Fig. 4). No significant elevation in the TH-positive cell number was found in the heterozygous MEN2B/+ mice compared with Wt controls. In the VTA, the numbers of TH-positive cells did not differ between the mice of the three genotypes (Fig. 4). There were no differences between Wt and MEN2B mice in mean volume sizes of the portions of SNpc and VTA used for stereological analysis (data not shown).

\section{Striatal DAT-positive varicosities}

The prominent increases in striatal DA levels and in striatal THand DAT-immunostainings in both heterozygous and homozygous MEN2B mice could be because of sprouting of dopaminergic neurons, because the number of $\mathrm{TH}$-positive cell was increased only in the SNpc of the homozygous MEN2B mice. Indeed, it has been shown that exogenously administered GDNF induces sprouting of dopaminergic fibers (Hudson et al., 1995; Tomac et al., 1995; Kordower et al., 2000).

To clarify whether constitutive Ret activity causes sprouting of dopaminergic neurons in MEN2B mice, we assessed the number of DAT-positive punctate structures in the striatum using a stereological technique. As shown in Figure 5, we found that the number of DAT-positive terminals in the homozygous MEN2B/ MEN2B mice was increased by $20 \%$ compared with Wt mice ( $p=0.0448$; Student's $t$ test $)$, and in the heterozygous $\mathrm{MEN} 2 \mathrm{~B} /+$ mice, no significant increase in the number of DATpositive terminals was found. Because the striatal volumes used for counting were of similar size in the Wt and MEN2B mice

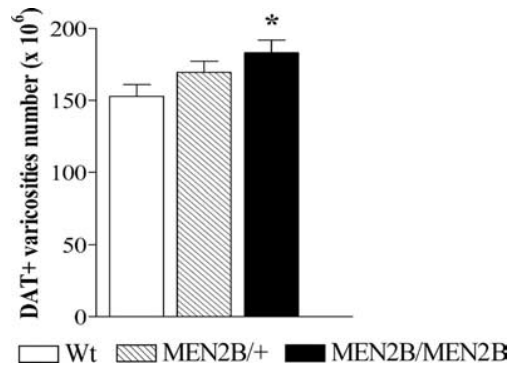

Figure 5. Stereological assessment of the numbers of DAT-positive varicosities in the striatum of Wt mice, heterozygous MEN2B/+ and homozygous MEN2B/MEN2B mice. Every fifth section (30 $\mu \mathrm{m}$ thickness) between planes 1.1 and 0.38 from bregma according to the atlas of Franklin and Paxinos (1997) was analyzed (4 sections per animal). Data are mean numbers of varicosities from seven to eight mice \pm SEM. The homozygous MEN2B mice had 20\% more of DAT-immunoreactive varicosities than the Wt mice ( ${ }^{*} p<0.05$ vs Wt mice; Student's $t$ test).

(data not shown), the density of DAT-positive varicosities was elevated similarly as the number of DAT-positive terminals (by $23 \%$ ) in the MEN2B/MEN2B mice compared with Wt mice (data not shown).

\section{Spontaneous and cocaine-induced locomotor activity}

Spontaneous activities in nonhabituated Wt, MEN2B/+, and MEN2B/MEN2B mice declined during the 60 min recording period in a similar way (genotype $\times$ time interaction, $p=0.43$ ) (Fig. 6). Paradoxically, mice of both MEN2B genotypes showed reduced locomotor activity when placed in a new environment (exploratory activity) compared with the activity of Wt mice (significant genotype effect, $p=0.0038$; repeated-measures ANOVA), but no differences in spontaneous activity between heterozygous and homozygous MEN2B mice were found (Fig. 6). However, when these mice were habituated and locomotor activity was recorded over $24 \mathrm{~h}$, no differences in the distances traveled or time points of activity peaks among the mice of the three genotypes were found (Fig. 6).

Next, the mice were given cocaine $(5,10$, or $20 \mathrm{mg} / \mathrm{kg})$ or saline, and locomotor activities were recorded for $30 \mathrm{~min}$. Cocaine significantly and dose-dependently increased locomotor activity in mice of all three genotypes. An overall genotype $\times$ treatment interaction analysis with two-way ANOVA showed that effects of cocaine differed between the $\mathrm{Wt}$ and MEN2B mice ( $p=0.0055$ ) (Fig. 7). Two-way ANOVA performed on individual cocaine doses showed that the effect of $5 \mathrm{mg} / \mathrm{kg}$ cocaine was similar in all genotypes (genotype effect, $p=0.9811$; genotype $\times$ treatment interaction, $p=0.3743$ ). However, 10 and $20 \mathrm{mg} / \mathrm{kg}$ cocaine increased locomotor activity significantly more in heterozygous MEN2B/+ and homozygous MEN2B/MEN2B mice than in Wt mice (genotype effect for $10 \mathrm{mg} / \mathrm{kg}, p=0.0024$ and for $20 \mathrm{mg} / \mathrm{kg}, p=0.0033$; genotype $\times$ treatment interaction for 10 $\mathrm{mg} / \mathrm{kg}, p=0.0005$ and for $20 \mathrm{mg} / \mathrm{kg}, p=0.0017$, respectively; two-way ANOVA). Furthermore, homozygous MEN2B mice treated with $20 \mathrm{mg} / \mathrm{kg}$ cocaine traveled a significantly longer distance than their correspondingly treated Wt littermates $(p<$ 0.01 , Tukey-Kramer post hoc test). Locomotor activities of salinetreated MEN2B mice and their Wt littermates did not differ significantly (Fig. 7).

\section{Discussion}

GDNF signaling via Ret can rescue and protect dopaminergic neurons and it is of great interest to study whether constitutive Ret signaling affects brain dopaminergic neurons. Because NCAM also functions as an alternative signaling receptor for 
GFLs, the significance of Ret signaling on the dopaminergic system in the brain could be revealed using MEN2B mice with a constitutively active Ret RTK.

In the present experiments, we found that Met919Thr mutation in knock-in MEN2B mice, which renders the Ret RTK constitutively active, robustly increases brain DA concentration. We also found a $26 \%$ increase in the number of $\mathrm{TH}$ positive cells in the SNpc of homozygous MEN2B mice. Consistent with the elevated striatal DA concentration, we found increased TH protein levels in the striatum and SN/VTA, as well as increased mRNA levels in the SN/VTA, suggesting that constitutive Ret activity increases DA concentration by increasing DA synthesis.

It has been shown that the MEN2B mutation leads to altered substrate specificity of the Ret catalytic domain (Santoro et al., 1995; Songyang et al., 1995). The present knowledge about Ret signaling pathways has been obtained mainly on oncogenic forms of Ret in cancerous cells or fibroblasts. To date, no substantial, qualitative differences between the oncogenic and ligandactivated Ret signaling pathways have been shown (Takahashi, 2001; Sariola and Saarma, 2003; Gujral et al., 2006). In that respect, our mouse model corresponds to permanent activation of Ret by GFLs.

The most prominent elevation of DA concentration (twofold) was seen in the dorsal striatum of the homozygous MEN2B mice and somewhat less in the heterozygous mice. In the ventral striatum and cortex, DA was similarly elevated (by 60-70\%) in both heterozygous and homozygous MEN2B mice. In the hypothalamus, DA concentration was elevated only in the homozygous mice, which agrees well with the low-expression level of the Ret receptor in this area (Trupp et al., 1997; Yu et al., 1998). This is in line with previous reports that exogenously administered GDNF increases DA levels and turnover in the striatum and SN of rodents (Hudson et al., 1995; Martin et al., 1996; Lapchak et al., 1997). Furthermore, we found that the MEN2B mutation selectively affects the dopaminergic system because the concentrations of 5-HT and NA were not affected, with the exception of a small increase in NA concentration in the lower brainstem. Because the monoamines do not pass the blood-brain barrier (Feldman et al., 1997), possible peripheral changes in the adrenals or in the sympathetic nervous system do not contribute to the changes in catecholamine levels we found in the brain of MEN2B mice. Thus, the elevated brain DA, most likely, results from the effect of constitutive Ret activity on the brain of MEN2B mice.

The elevated DA concentrations in the MEN2B mice are probably because of increased DA synthesis and not because of DA cell number, which was increased only in the SNpc of homozygous mice. This is supported by our finding that TH mRNA levels were increased in SN/VTA, and TH protein levels were found to be increased in the striatum and SN/VTA of MEN2B mice. Indeed, previous studies have shown that administration of GDNF promotes the transcription of the $\mathrm{TH}$ gene and the stability of $\mathrm{TH}$ mRNA (Xiao et al., 2002). Also, GDNF treatment has been found to increase TH phosphorylation, enhancing its activity and DA synthesis (Kobori et al., 2004; Salvatore et al., 2004). However, after prolonged GDNF treatment, mRNA and protein levels of $\mathrm{TH}$ were found to be decreased without changes in DA concentrations (Lu and Hagg, 1997; Rosenblad et al., 2003; Georgievska

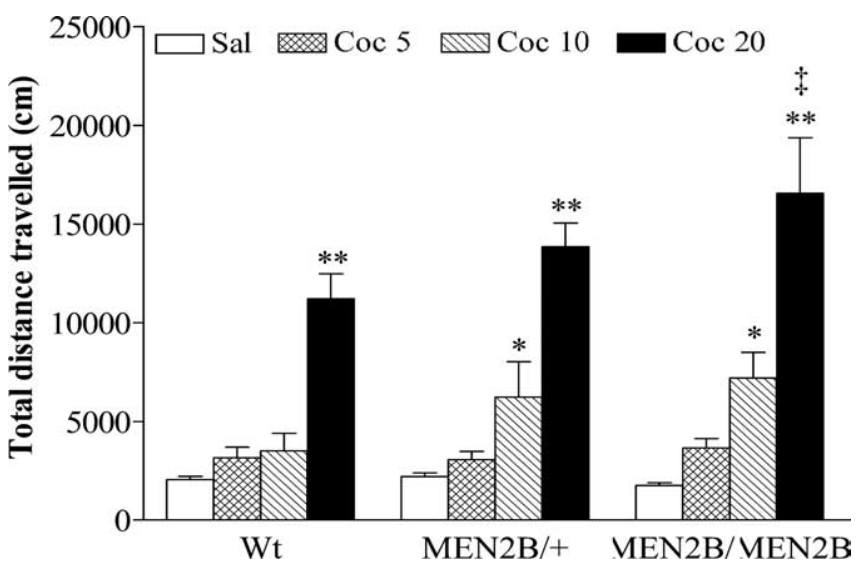

Figure 7. The effects of acute cocaine ( $\mathrm{COC}$ ) administration on locomotor activities of Wt, heterozygous MEN2B/+, and homozygous MEN2B/MEN2B mice. Saline or cocaine $(5,10$, or 20 $\mathrm{mg} / \mathrm{kg}$ ) were given intraperitoneally immediately before starting the recording. Data are means \pm SEM of total distances traveled during $30 \min (n=7-49) .{ }^{*} p<0.05,{ }^{* *} p<0.01$ compared with corresponding saline-treated mice; ${ }^{\ddagger} p<0.01$ compared with Wt mice given 20 $\mathrm{mg} / \mathrm{kg}$ cocaine (Tukey-Kramer post hoc test).

et al., 2004). This was proposed to be a compensatory response to the initial stimulatory effects of GDNF on TH to maintain longterm dopaminergic neuron function within the normal range. Contrary to the long-term GDNF overexpression, in MEN2B mice both the DA tissue levels and the levels of TH mRNA and protein were elevated, showing that no such compensation at the level of TH occurs in these mice. This discrepancy could be because of the fact that in MEN2B mice, Ret signaling is permanently activated since early development, which is actively changing and shaping the development of the dopaminergic system, whereas in most animal models, exogenous GDNF is administered into already mature dopaminergic system and activity of Ret is increased by exogenous GDNF.

It is possible that compensatory responses, including upregulation of DA uptake, occur in the dopaminergic system of the MEN2B mice. Indeed, we found increased striatal DAT protein levels in MEN2B mice. Also, our finding that the MEN2B mice were more sensitive to cocaine is in line with the upregulation of DAT we found in the striatum of these mice. Because dopaminergic neuron endings of MEN2B mice are apparently loaded with DA and contain higher levels of DAT, cocaine, by blocking DAT, would probably increase the extracellular DA and locomotor activity more in the MEN2B mice than in the Wt mice. However, we found that the activity of MEN2B mice in the $24 \mathrm{~h}$ loco- 
motor activity experiment was similar to that of Wt mice and that their exploratory activity was even reduced compared with $\mathrm{Wt}$ mice. Also, our preliminary data using microdialysis in freely moving mice show that the extracellular DA concentrations do not differ between the Wt and homozygous MEN2B/MEN2B mice (Airavaara et al., 2006). Thus, we speculate that despite the increased DA synthesis, the dopaminergic neuron function in the MEN2B mice is maintained within the normal range. Indeed, our findings show the remarkable capacity of the brain dopaminergic system for compensatory alterations.

We found that adult homozygous MEN2B mice had 26\% more TH-positive cells in the SNpc than the Wt mice, whereas no difference was found in the VTA. In contrast, adult GDNFoverexpressing mice had increased the number of dopaminergic neurons in the VTA but not in the SN (Kholodilov et al., 2004). However, in that study, GDNF was overexpressed only in certain brain areas, and it was under the control of an artificial promoter, whereas in our mice, the mutated Ret (Met919Thr) was expressed under control of the natural, endogenous Ret promoter. Also, in models in which GDNF levels are elevated, increase in Ret signaling is possibly limited by the availability of GFR $\alpha$ coreceptors, whereas in MEN2B mice in which signaling receptor activity is increased independently of ligand, such limitations are excluded.

Studies on knock-out mice suggest that GDNF-Ret signaling is not important for prenatal, embryonic development of nigral dopaminergic neurons (Marcos and Pachnis, 1996; Moore et al., 1996; Pichel et al., 1996; Sanchez et al., 1996; Enomoto et al., 1998). Thus, the increased number of SNpc TH-positive cells in the homozygous MEN2B mice is likely to arise during the postnatal development of the nigrostriatal dopaminergic system. It has been shown that nigral dopaminergic neurons undergo apoptosis during the first three postnatal weeks, and in mice overexpressing GDNF in dopaminergic targets, GDNF promotes postnatal survival of nigrostriatal dopaminergic neurons during the first phase of natural cell death by suppressing apoptosis (Oo and Burke, 1997; Burke et al., 1998; Oo et al., 2003; Kholodilov et al., 2004). Thus, the increased number of TH-positive SNpc neurons in MEN2B mice could be because of neurotrophic support delivered by constitutively active Ret rescuing more developing dopaminergic neurons during the postnatal apoptotic phases. However, it has been shown that the majority of dopaminergic neurons appear during the first three postanatal weeks in rodents as a result of increased number of cells acquiring the DA phenotype (Lieb et al., 1996; Jackson-Lewis et al., 2000). Consequently, another explanation for the increased number of $\mathrm{TH}$-positive cells in MEN2B mice is that the constitutive activity of Ret leads to a larger proportion of developing cells acquiring a dopaminergic phenotype during postnatal development.

The physiological role of Ret in the mice in which Ret was specifically deleted in dopaminergic neurons was investigated in two recent studies. In 8- to 12-month-old mice (Jain et al., 2006), there were neither changes found in the number and size of dopaminergic neurons in the SNpc and VTA, nor was there a difference in the DA fiber density and DA levels in the striatum. However, in the genetically almost identical, but older (12-24 months) conditional Ret knock-outs (Kramer et al., 2007), progressive loss of dopaminergic neurons in the SNpc and degeneration of DA nerve terminals in the striatum were found, supporting our findings that Ret plays an important role in the regulation of the number of dopaminergic neurons and DA levels. The opposing results from these two studies, however, are not necessar- ily contradictory and could be simply because of different ages at which the mice were examined.

When examining DAT-IR punctate structures, we found $\sim 20 \%$ increase in their number in the striatum of homozygous MEN2B mice that correlates with the $26 \%$ increase of $\mathrm{TH}$ positive cell number in the SN. Thus, we assumed that no additional sprouting of dopaminergic neurons occurred under constitutively active Ret in MEN2B mice. Exogenous GDNF induces sprouting of DA fibers toward the injection site in lesion models in rodents and primates as well as in clinical studies on Parkinsonian patients (Akerud et al., 1999; Kordower et al., 2000; Love et al., 2005). However, it is not clear from these studies whether GDNF induced sprouting or just upregulation of dopaminergic activity in spared but inactive fibers, especially keeping in mind that lesioning the dopaminergic system itself leads to compensatory sprouting of dopaminergic neurons (Blanchard et al., 1995; Bezard et al., 2000; Finkelstein et al., 2000). Indeed, in models where long-term GDNF overexpression was achieved in the intact dopaminergic system (Rosenblad et al., 2003; Georgievska et al., 2004; Kholodilov et al., 2004), the presynaptic terminal density was unchanged.

It has been shown that GDNF prevents 6-hydroxydopamine induced degeneration of LC noradrenergic neurons and promotes their phenotype in vivo (Arenas et al., 1995). However, we did not find any changes in NA levels in target areas of LC noradrenergic neurons, indicating that Ret-MEN2B mutation does not affect the LC neurons. This agrees with previous findings that GDNF is not needed for the development of LC noradrenergic neurons (Granholm et al., 1997; Holm et al., 2003). However, the lower brainstem also contains A5 noradrenergic neurons that project to autonomic nuclei of the brainstem and spinal cord. It has been shown that A5 noradrenergic neurons are GDNF dependent because the number of A5 neurons decreases in GDNFnull mutants (Huang et al., 2005). This implies that A5 noradrenergic neurons respond to the Ret-MEN2B mutation, and this might be behind the modest increase in NA levels in the lower brainstem of MEN2B mice.

In conclusion, our results show that sustained activity of Ret selectively and dramatically increases cerebral concentrations of DA by increasing DA synthesis. In addition, we found an increased number of TH-positive cells in the SNpc of homozygous MEN2B mice. Thus, these mice represent a novel and highly important model in research on the physiological and pathophysiological role of GDNF-Ret signaling for dopaminergic systems. Also, because no neurological symptoms have been reported for MEN2B patients, our findings from MEN2B mice warrant further neurological studies on humans with the MEN2B syndrome. Finally, we think it is important to study whether constitutive activity of Ret protects the dopaminergic neurons in neurodegeneration, and currently, we are testing this in the MPTP (1-methyl-4-phenyl-1,2,3,6-tetrahydropyridine) model of Parkinson's disease.

\section{References}

Airavaara M, Mijatovic J, Vihavainen T, Piepponen TP, Saarma M, Ahtee L (2006) In heterozygous GDNF knockout mice the response of striatal dopaminergic system to acute morphine is altered. Synapse 59:321-329.

Akerud P, Alberch J, Eketjall S, Wagner J, Arenas E (1999) Differential effects of glial cell line-derived neurotrophic factor and neurturin on developing and adult substantia nigra dopaminergic neurons. J Neurochem 73:70-78.

Arenas E, Trupp M, Akerud P, Ibanez CF (1995) GDNF prevents degeneration and promotes the phenotype of brain noradrenergic neurons in vivo. Neuron 15:1465-1473. 
Beck KD, Irwin I, Valverde J, Brennan TJ, Langston JW, Hefti F (1996) GDNF induces a dystonia-like state in neonatal rats and stimulates dopamine and serotonin synthesis. Neuron 16:665-673.

Bezard E, Dovero S, Imbert C, Boraud T, Gross CE (2000) Spontaneous long-term compensatory dopaminergic sprouting in MPTP-treated mice. Synapse 38:363-368.

Blanchard V, Chritin M, Vyas S, Savasta M, Feuerstein C, Agid Y, Javoy-Agid F, Raisman-Vozari R (1995) Long-term induction of tyrosine hydroxylase expression: compensatory response to partial degeneration of the dopaminergic nigrostriatal system in the rat brain. J Neurochem 64:1669-1679.

Burke RE, Antonelli M, Sulzer D (1998) Glial cell line-derived neurotrophic growth factor inhibits apoptotic death of postnatal substantia nigra dopamine neurons in primary culture. J Neurochem 71:517-525.

Chao CC, Ma YL, Chu KY, Lee EH (2003) Integrin alphav and NCAM mediate the effects of GDNF on DA neuron survival, outgrowth, DA turnover and motor activity in rats. Neurobiol Aging 24:105-116.

Durbec P, Marcos-Gutierrez CV, Kilkenny C, Grigoriou M, Wartiowaara K, Suvanto P, Smith D, Ponder B, Costantini F, Saarma M, et al (1996) GDNF signalling through the Ret receptor tyrosine kinase. Nature 381:789-793.

Eng C (1999) RET proto-oncogene in the development of human cancer. J Clin Oncol 17:380-393.

Enomoto H, Araki T, Jackman A, Heuckeroth RO, Snider WD, Johnson Jr EM, Milbrandt J (1998) GFR alphal-deficient mice have deficits in the enteric nervous system and kidneys. Neuron 21:317-324.

Feldman RS, Meyer JS, Quenzer LF (1997) Principles of pharmacology. In: Principles of neuropsychopharmacology, pp 1-25. Sunderland, MA: Sinauer Associates.

Finkelstein DI, Stanic D, Parish CL, Tomas D, Dickson K, Horne MK (2000) Axonal sprouting following lesions of the rat substantia nigra. Neuroscience 97:99-112.

Franklin K, Paxinos G (1997) The mouse brain in stereotaxic coordinates. San Diego: Academic.

Gash DM, Zhang Z, Ovadia A, Cass WA, Yi A, Simmerman L, Russell D, Martin D, Lapchak PA, Collins F, Hoffer BJ, Gerhardt GA (1996) Functional recovery in parkinsonian monkeys treated with GDNF. Nature 380:252-255.

Georgievska B, Kirik D, Bjorklund A (2004) Overexpression of glial cell linederived neurotrophic factor using a lentiviral vector induces time- and dose-dependent downregulation of tyrosine hydroxylase in the intact nigrostriatal dopamine system. J Neurosci 24:6437-6445.

Gill SS, Patel NK, Hotton GR, O’Sullivan K, McCarter R, Bunnage M, Brooks DJ, Svendsen CN, Heywood P (2003) Direct brain infusion of glial cell line-derived neurotrophic factor in Parkinson disease. Nat Med 9:589-595.

Glazner GW, Mu X, Springer JE (1998) Localization of glial cell line-derived neurotrophic factor receptor alpha and c-ret mRNA in rat central nervous system. J Comp Neurol 391:42-49.

Golden JP, DeMaro JA, Osborne PA, Milbrandt J, Johnson Jr EM (1999) Expression of neurturin, GDNF, and GDNF family-receptor mRNA in the developing and mature mouse. Exp Neurol 158:504-528.

Granholm AC, Srivastava N, Mott JL, Henry S, Henry M, Westphal H, Pichel JG, Shen L, Hoffer BJ (1997) Morphological alterations in the peripheral and central nervous systems of mice lacking glial cell line-derived neurotrophic factor (GDNF): immunohistochemical studies. J Neurosci 17:1168-1178.

Granholm AC, Reyland M, Albeck D, Sanders L, Gerhardt G, Hoernig G, Shen L, Westphal H, Hoffer B (2000) Glial cell line-derived neurotrophic factor is essential for postnatal survival of midbrain dopamine neurons. J Neurosci 20:3182-3190.

Gujral TS, Singh VK, Jia Z, Mulligan LM (2006) Molecular mechanisms of RET receptor-mediated oncogenesis in multiple endocrine neoplasia $2 \mathrm{~B}$. Cancer Res 66:10741-10749.

Gundersen HJ, Bagger P, Bendtsen TF, Evans SM, Korbo L, Marcussen N, Moller A, Nielsen K, Nyengaard JR, Pakkenberg B, et al (1988) The new stereological tools: disector, fractionator, nucleator and point sampled intercepts and their use in pathological research and diagnosis. APMIS 96:857-881.

Hoffer BJ, Hoffman A, Bowenkamp K, Huettl P, Hudson J, Martin D, Lin LF, Gerhardt GA (1994) Glial cell line-derived neurotrophic factor reverses toxin-induced injury to midbrain dopaminergic neurons in vivo. Neurosci Lett 182:107-111.

Hokfelt T, Martenson R, Bjorklund A, Kleinau S, Goldstein M (1984) Distributional maps of tyrosine hydroxylase immunoreactive neurons in the rat brain. In: Classical transmitters in the CNS, handbook of chemical neuroanatomy (Bjorklund A, Hokfelt T, eds), pp 277-379. Amsterdam: Elsevier.

Holm PC, Rodriguez FJ, Kresse A, Canals JM, Silos-Santiago I, Arenas E (2003) Crucial role of TrkB ligands in the survival and phenotypic differentiation of developing locus coeruleus noradrenergic neurons. Development 130:3535-3545.

Huang L, Guo H, Hellard DT, Katz DM (2005) Glial cell line-derived neurotrophic factor (GDNF) is required for differentiation of pontine noradrenergic neurons and patterning of central respiratory output. Neuroscience 130:95-105.

Hudson J, Granholm AC, Gerhardt GA, Henry MA, Hoffman A, Biddle P, Leela NS, Mackerlova L, Lile JD, Collins F, et al (1995) Glial cell linederived neurotrophic factor augments midbrain dopaminergic circuits in vivo. Brain Res Bull 36:425-432.

Jain S, Golden JP, Wozniak D, Pehek E, Johnson Jr EM, Milbrandt J (2006) RET is dispensable for maintenance of midbrain dopaminergic neurons in adult mice. J Neurosci 26:11230-11238.

Kholodilov N, Yarygina O, Oo TF, Zhang H, Sulzer D, Dauer W, Burke RE (2004) Regulation of the development of mesencephalic dopaminergic systems by the selective expression of glial cell line-derived neurotrophic factor in their targets. J Neurosci 24:3136-3146.

Kobori N, Waymire JC, Haycock JW, Clifton GL, Dash PK (2004) Enhancement of tyrosine hydroxylase phosphorylation and activity by glial cell line-derived neurotrophic factor. J Biol Chem 279:2182-2191.

Kordower JH, Emborg ME, Bloch J, Ma SY, Chu Y, Leventhal L, McBride J, Chen EY, Palfi S, Roitberg BZ, Brown WD, Holden JE, Pyzalski R, Taylor MD, Carvey P, Ling Z, Trono D, Hantraye P, Deglon N, Aebischer P (2000) Neurodegeneration prevented by lentiviral vector delivery of GDNF in primate models of Parkinson's disease. Science 290:767-773.

Kramer ER, Aron L, Ramakers GM, Seitz S, Zhuang X, Beyer K, Smidt MP, Klein R (2007) Absence of Ret Signaling in Mice Causes Progressive and Late Degeneration of the Nigrostriatal System. PLoS Biol 5:e39.

Lapchak PA, Jiao S, Collins F, Miller PJ (1997) Glial cell line-derived neurotrophic factor: distribution and pharmacology in the rat following a bolus intraventricular injection. Brain Res 747:92-102.

Lieb K, Andersen C, Lazarov N, Zienecker R, Urban I, Reisert I, Pilgrim C (1996) Pre- and postnatal development of dopaminergic neuron numbers in the male and female mouse midbrain. Brain Res Dev Brain Res 94:37-43.

Lin LF, Doherty DH, Lile JD, Bektesh S, Collins F (1993) GDNF: a glial cell line-derived neurotrophic factor for midbrain dopaminergic neurons. Science 260:1130-1132.

Love S, Plaha P, Patel NK, Hotton GR, Brooks DJ, Gill SS (2005) Glial cell line-derived neurotrophic factor induces neuronal sprouting in human brain. Nat Med 11:703-704.

Lu X, Hagg T (1997) Glial cell line-derived neurotrophic factor prevents death, but not reductions in tyrosine hydroxylase, of injured nigrostriatal neurons in adult rats. J Comp Neurol 388:484-494.

Marcos C, Pachnis V (1996) The effect of the ret- mutation on the normal development of the central and parasympathetic nervous systems. Int J Dev Biol Suppl 1:137S-138S.

Martin D, Miller G, Cullen T, Fischer N, Dix D, Russell D (1996) Intranigral or intrastriatal injections of GDNF: effects on monoamine levels and behavior in rats. Eur J Pharmacol 317:247-256.

Moore MW, Klein RD, Farinas I, Sauer H, Armanini M, Phillips H, Reichardt LF, Ryan AM, Carver-Moore K, Rosenthal A (1996) Renal and neuronal abnormalities in mice lacking GDNF. Nature 382:76-79.

Nosrat CA, Tomac A, Hoffer BJ, Olson L (1997) Cellular and developmental patterns of expression of Ret and glial cell line-derived neurotrophic factor receptor alpha mRNAs. Exp Brain Res 115:410-422.

Oo TF, Burke RE (1997) The time course of developmental cell death in phenotypically defined dopaminergic neurons of the substantia nigra. Brain Res Dev Brain Res 98:191-196.

Oo TF, Kholodilov N, Burke RE (2003) Regulation of natural cell death in dopaminergic neurons of the substantia nigra by striatal glial cell linederived neurotrophic factor in vivo. J Neurosci 23:5141-5148. 
Pachnis V, Mankoo B, Costantini F (1993) Expression of the c-ret protooncogene during mouse embryogenesis. Development 119:1005-1017.

Paratcha G, Ledda F, Ibanez CF (2003) The neural cell adhesion molecule NCAM is an alternative signaling receptor for GDNF family ligands. Cell 113:867-879.

Parish CL, Finkelstein DI, Drago J, Borrelli E, Horne MK (2001) The role of dopamine receptors in regulating the size of axonal arbors. J Neurosci 21:5147-5157.

Pichel JG, Shen L, Sheng HZ, Granholm AC, Drago J, Grinberg A, Lee EJ, Huang SP, Saarma M, Hoffer BJ, Sariola H, Westphal H (1996) Defects in enteric innervation and kidney development in mice lacking GDNF. Nature 382:73-76.

Pothos EN, Davila V, Sulzer D (1998) Presynaptic recording of quanta from midbrain dopamine neurons and modulation of the quantal size. J Neurosci 18:4106-4118.

Roffler-Tarlov S, Sharman DF, Tegerdine P (1971) 3,4-dihydroxyphenylacetic acid and 4-hydroxy-3-methoxyphenylacetic acid in the mouse striatum: a reflection of intra- and extra-neuronal metabolism of dopamine? Br J Pharmacol 42:343-351.

Rosenblad C, Kirik D, Bjorklund A (2000) Sequential administration of GDNF into the substantia nigra and striatum promotes dopamine neuron survival and axonal sprouting but not striatal reinnervation or functional recovery in the partial 6-OHDA lesion model. Exp Neurol 161:503-516.

Rosenblad C, Georgievska B, Kirik D (2003) Long-term striatal overexpression of GDNF selectively downregulates tyrosine hydroxylase in the intact nigrostriatal dopamine system. Eur J Neurosci 17:260-270.

Salvatore MF, Zhang JL, Large DM, Wilson PE, Gash CR, Thomas TC, Haycock JW, Bing G, Stanford JA, Gash DM, Gerhardt GA (2004) Striatal GDNF administration increases tyrosine hydroxylase phosphorylation in the rat striatum and substantia nigra. J Neurochem 90:245-254.

Sanchez MP, Silos-Santiago I, Frisen J, He B, Lira SA, Barbacid M (1996) Renal agenesis and the absence of enteric neurons in mice lacking GDNF. Nature 382:70-73.

Santoro M, Carlomagno F, Romano A, Bottaro DP, Dathan NA, Grieco M, Fusco A, Vecchio G, Matoskova B, Kraus MH, et al (1995) Activation of RET as a dominant transforming gene by germline mutations of MEN2A and MEN2B. Science 267:381-383.

Sariola H, Saarma M (2003) Novel functions and signalling pathways for GDNF. J Cell Sci 116:3855-3862.

Sauer H, Rosenblad C, Bjorklund A (1995) Glial cell line-derived neurotrophic factor but not transforming growth factor beta 3 prevents delayed degeneration of nigral dopaminergic neurons following striatal 6-hydroxydopamine lesion. Proc Natl Acad Sci USA 92:8935-8939.
Slevin JT, Gerhardt GA, Smith CD, Gash DM, Kryscio R, Young B (2005) Improvement of bilateral motor functions in patients with Parkinson disease through the unilateral intraputaminal infusion of glial cell linederived neurotrophic factor. J Neurosurg 102:216-222.

Smith-Hicks CL, Sizer KC, Powers JF, Tischler AS, Costantini F (2000) C-cell hyperplasia, pheochromocytoma and sympathoadrenal malformation in a mouse model of multiple endocrine neoplasia type $2 \mathrm{~B}$. EMBO J 19:612-622.

Songyang Z, Carraway III KL, Eck MJ, Harrison SC, Feldman RA, Mohammadi M, Schlessinger J, Hubbard SR, Smith DP, Eng C, et al (1995) Catalytic specificity of protein-tyrosine kinases is critical for selective signalling. Nature 373:536-539.

Takahashi M (2001) The GDNF/RET signaling pathway and human diseases. Cytokine Growth Factor Rev 12:361-373.

Takahashi M, Cooper GM (1987) ret transforming gene encodes a fusion protein homologous to tyrosine kinases. Mol Cell Biol 7:1378-1385.

Tomac A, Lindqvist E, Lin LF, Ogren SO, Young D, Hoffer BJ, Olson L (1995) Protection and repair of the nigrostriatal dopaminergic system by GDNF in vivo. Nature 373:335-339.

Treanor JJ, Goodman L, de Sauvage F, Stone DM, Poulsen KT, Beck CD, Gray C, Armanini MP, Pollock RA, Hefti F, Phillips HS, Goddard A, Moore MW, Buj-Bello A, Davies AM, Asai N, Takahashi M, Vandlen R, Henderson CE, Rosenthal A (1996) Characterization of a multicomponent receptor for GDNF. Nature 382:80-83.

Trupp M, Arenas E, Fainzilber M, Nilsson AS, Sieber BA, Grigoriou M, Kilkenny C, Salazar-Grueso E, Pachnis V, Arumäe U, Sariola H, Saarma M, Báñez CF (1996) Functional receptor for GDNF encoded by the c-ret proto-oncogene. Nature 381:785-789.

Trupp M, Belluardo N, Funakoshi H, Ibanez CF (1997) Complementary and overlapping expression of glial cell line-derived neurotrophic factor (GDNF), c-ret proto-oncogene, and GDNF receptor- $\alpha$ indicates multiple mechanisms of trophic actions in the adult rat CNS. J Neurosci 17:3554-3567.

Wood PL, Altar CA (1988) Dopamine release in vivo from nigrostriatal, mesolimbic, and mesocortical neurons: utility of 3-methoxytyramine measurements. Pharmacol Rev 40:163-187.

Xiao H, Hirata Y, Isobe K, Kiuchi K (2002) Glial cell line-derived neurotrophic factor up-regulates the expression of tyrosine hydroxylase gene in human neuroblastoma cell lines. J Neurochem 82:801-808.

Yu T, Scully S, Yu Y, Fox GM, Jing S, Zhou R (1998) Expression of GDNF family receptor components during development: implications in the mechanisms of interaction. J Neurosci 18:4684-4696. 